\title{
Patterns of language in polyglossic urban areas and multilingual regions and institutions: a Swiss case study
}

\author{
GEORGES LÜDI, KATHARINA HÖCHLE \\ and PATCHAREERAT YANAPRASART
}

Abstract

Growing mobility of important parts of the world's population has led to a massive increase in multilingualism in post-modern societies and a lasting change from homoglossic to polyglossic communities with important "deterritorialised" linguistic minorities, mostly plurilingual to a variable degree. Ideologies and practices of communication in old and new multilingual contexts vary largely. The "solutions" for overcoming potential problems go from using a lingua franca (often English), inventing pidgin like emergent varieties, choosing the language of one of the interlocutors known (partially) by the others (namely in the case of immigrants), insisting on receptive competences (everybody uses his or her own language, e. g. in officially multilingual institutions), to various forms of mixed speech and, of course, to interpretation and translation processes. Drawing on extensive field work in bilingual institutions and multilingual companies in Europe, particularly in Switzerland, we propose to discuss various ways of mobilizing multilingual repertoires in situations of cross-linguistic and intercultural communication. The analyzed data will mainly consist of dyadic and polyadic oral interactions. It will also include written texts and signs that are part of the linguistic landscape. Our work is grounded in the assumption that multilingualism is no longer considered a marginal phenomenon, only of interest to specialists, but instead a characteristic of the majority of human beings.

Keywords: plurilingualism; multilingual competence; linguistic resource; polyglossic communities.

\section{From homoglossic to polyglossic images of human society?}

From their beginnings human societies have been plurilingual. But the prevalent image of linguistic diversity was that of a patchwork of rather homogeneous 
language communities that were in contact peripherally, through trade relations and exogamous marriages, but were fundamentally monolingual. In modern urban contexts, such communities penetrate each other in new and original ways. However, the usual representations of languages in contact continue to be shaped by monolingual traditions and do not totally match the demographic distribution of languages.

The background of these "monolingual ideologies" is a very old one. It is founded on the received wisdom that monolingualism represents an original state, intended by God and/or politically legitimised by human beings. To an extent this stereotype can be found in the Bible (e.g. in the image of the tower of Babel [Genesis 11, 6-7]) and in Greek philosophy, starting with Aristotle. From the French Revolution (Barère 1794; Grégoire 1794) to World War I, national sentiments start to be treated as religious concerns, under the influence of Romantic ideas (Herder 1891 [1794]; Fichte 1808, etc.); they are discussed with metaphors borrowed from religious history, and build the myth of the "nation" as reflected in a common language. The process of standardization of "national languages" was determined by, and at the same time influenced, discourses like "one nation, one language".

Within this framework, individual bilingualism was perceived as dangerous in many ways: a menace to the singular culture attached to each language, and to discourse-transmitted knowledge of all varieties. Bilinguals, particularly early bilinguals, would have their cognitive and social identity threatened. Similarly language contact was mistrusted, even in areas known for their bilingualism such as Alsace or Switzerland. If studies in multilingualism were undertaken, they depended on a monolingual, theoretical infrastructure (Lüdi 2006; Lüdi and Py 2009). Multilingualism represented, so to say, a duplication of monolingualism. In the following pages, we will question these assumptions, not just by comparing them with actual practices, but also with the discourse of numerous interviewees on their practices. Which other, new, representations emerge from these experiences? How do we have to modify theoretical models in order to explain these experiences - and what could be the consequences for new forms of language management and policy?

\section{Monolingual answers to the challenge of communication in an increasing globalized world?}

When international tourists want to buy a train ticket at Basel's main station, they do not need to use their German travel phrase book. They can address the clerk in English and will get an answer in the same language, as shown in the following example: ${ }^{1}$ 
(1)

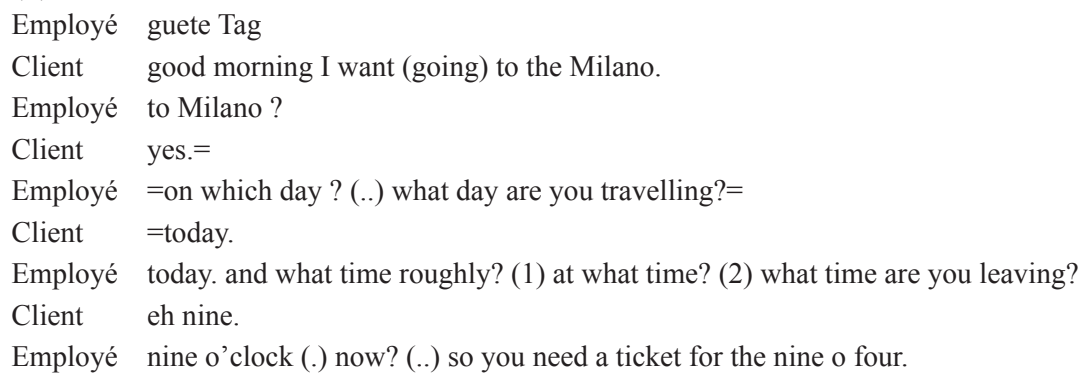

The maxim for the mostly plurilingual clerk working at Basel's main station is: if you can, speak the national language used by the client; with foreigners, speak English. This rule of thumb is widely accepted in the tourism industry, in Switzerland, and worldwide (Duchêne 2009). It is grounded in the experience that English is by far the most frequently learned L2. This involves the assumption that the best way to solve the world's communicative problems is to use English ${ }^{2}$ as lingua franca, i.e. as vehicular language between people who do not consider English their first language.

English as a lingua franca is nothing more than a useful tool: it is a "language for communication".... And because of the variety of functional uses of global English, English has also a great potential for promoting international understanding. (Juliane House, Guardian Weekly, April 19, 2001)

This opinion is very frequently heard in interviews with leaders of opinion interviewed in the DYLAN project throughout Europe. Currently, ELF is the dominant language of international business, science and technology; for example, international companies increasingly use English as their corporate language (e.g. Vollstedt 2002; Louhiala-Salminen et al. 2005; Charles 2007). For instance, this is the case for Pharma A and B, two leading pharmaceutical companies based in Basel. As the head of one of Pharma A's research labs put it, "all reports, all official documents, the study plan, etc. have to be in English". Furthermore, the importance of competences in English to the recruitment policy and promotion policy is obvious (Lüdi et al. [Forthcoming] for Pharma A and Berchtold [2009] for Pharma B).

A meeting of the editorial board of Pharma A's internal magazine (which is published in three languages: German, French and English) started in German because all of its members are German speaking, except for one person who speaks it well as L2. But when the head of the communications department joins his team, everyone at the meeting switches to English: 
(2)

SM: [also jetzt (.) die die modische farbkonstellation jetzt rein aus der graphischen sprache her (ist) sicherlich irgendwie son klinisches blau so türkis grün blau so was gewesen das wär chic gewesen mit dem braun jetzt rein (.) nur also auch von (.) von der graphiksprache die (.) mir jetzt zumindest so bekannt ist dass man halt braun (.) dass man das mit hellen tönen mischt + mit $+($ (the door opens and PW enters)) blau[tönen (.)

?: $\quad[\mathrm{a}:$

?: $\quad[(\mathrm{h})(\mathrm{h})[(\mathrm{h})(($ laughters $))$

SM: $\quad$ [and now its getting (.) $[(\mathrm{h})$

PW: [the language intruder

[once again

SM: [switch in englisch $(h)(h)[(h)$

?: $\quad[(\mathrm{h})$

PW: for their benefit=

? =(they) only [got started

SM: $\quad[(\mathrm{xxx})$ die von [von der uni=

PW: [sorry about that (again)

JK: $\quad=$ ah jä [jä

SM: [beobacht [mal

BK?: [thats great

JK: $\quad[j a ̈(h)$

PW: [yeah well it shows profile

?: $\quad$ (h) $[(\mathrm{h})$

CF: $\quad[(\mathrm{xxx}) \mathrm{am}($.$) Christoph you said we have to use white (..) who says we have to$ use white we? (.)

At first glance, this interaction exemplifies the predominance of English. One could argue, however, that it shows the diversity of language choices, depending of course, on the make up of speakers present in the interaction. In fact, the meeting can be said to be bilingual (even trilingual if we take into account that the informal start was in Swiss German) and what we just observed was a participant-related change of the language choice. So, in a way, both examples given heretofore illustrate that ELF is chosen in specific settings only (foreign client, foreign boss) and agreed by those present as a locally negotiated alternative to other forms of communication.

This interpretation is grounded in new conceptions of "multilingual competences". They are viewed less in terms of formal (syntactic) knowledge and more as a set of linguistic resources available to members of a community for socially significant interaction. The totality of these resources constitute the linguistic repertoire of a person or a community (Gal 1986), not in an "additive" sense (the multilingual person as a kind of combination of various mono- 
lingual components), but in a holistic view (Grosjean 1985, 2001; Lüdi and Py 2003 [1986]) which values the integration of partial competences (Council of Europe 2001). ${ }^{3}$ But the notion of competence itself has undergone profound changes in the course of the 20th century. The "Hymesian revolution" recognized the plural nature of communicative capacities and allowed for accounts of the discursive and pragmatic dimensions of language use. However, for Hymes and his successors (for example, Canale and Swain 1980), the focus remains on the observable competence of the learner and on the know-how deposited in his or her brain. There were several intents to move beyond these approaches which tended to misjudge the situational sensitivity of competences (regardless of whether this competence is linguistic or pragmatic) and the complexity of the processes in which these are implemented, as part of the practical activities of learners, users and their interlocutors. An interactionist interpretation of competence, by contrast, is based upon a contextualized and collective conception of activities and of human cognition, while focusing on the central role that practical communication (and, therefore, social action) plays in their formatting. This perspective deconstructs, in a radical manner, any individualizing, decontextualized and isolating definition of linguistic and communicative competences. Research on language acquisition confirms the high degree of unpredictability and complex dynamics of face-to-face communication in authentic interaction (Pekarek 1999). At the same time it sheds new light on the ways native, and non-native, speakers of a language take mutual profit from their entire repertoires using their respective first languages and other support languages (Bono 2008; Bono and Stratilaki 2009). According to this concept, the elaboration and the mobilization of competences are configured in the course of practical activities that are linked to specific sociocultural contexts and to particular forms of action, interaction and intersubjectivity (Pekarek Doehler 2005; Lüdi 2004, 2006, 2007d; Berthoud 2008). Having concentrated on examples of internal communication at work in Switzerland, we will now ask ourselves in which way the use of monolingual models (only one national language or, progressively, the exclusive use of English) or, on the contrary, plurilingual models like, for example, the "Swiss model" of receptive bilingualism (everyone speaks his or her language and understands the other, i.e. mobilizes exclusively passive competences in the other's language ${ }^{4}$ - - prevail in real life or, better, how these ideal types are reflected in daily contacts. In fact, we formulate the hypothesis that, in a situation of shared, even asymmetric bilingualism, other forms of communication will emerge. We propose to analyze key examples as part of a search for empirical evidence without any claim for statistical relevance. 


\section{A plurilingual "linguistic landscape"}

Before continuing, however, with the analysis of examples of oral interaction, we propose to have a look at the ways plurilingualism manifests itself in the written public space. Indeed, as a consequence of massive demographic changes, the urban linguistic landscape 5 ("cityscape") of many European cities is characterized by a growing presence of "other languages", i.e. languages that are not traditionally used in the respective area. In Basel, a Swiss city located at the French and German border and officially monolingual German speaking, we can find signs of more than 50 languages in use, among them German, English, French, Italian, Romanche, Spanish, Portuguese, Russian, Chinese, Japanese, Turkish, Arabic, Tibetan, Serbian, Albanian, Tamil, etc. Certainly the most striking fact is the presence in many shop windows, billboards, etc., of signs combining elements of various languages. Sometimes, the same message is translated into different languages, for the benefit of tourists. But the sequences in different languages mostly perform complementary functions. The combination used most often is that of German and English:

- Kids \& Co - Mode für Kinder

- Johann Wanner - Weihnachtsbaumschmuckausstattungsgeschäft - devote yourself to glamour

- Last Season — Schmuck \& Uhren Outlet der Chronometrie Spinnler + Schweizer AG

- Stichkabinett - René Tschirren Modern Arts

- WoMenArt - Schmuck für Frau und Mann; great waves schmuck-atelier

- Coiffure Black and White - Damen + Herren - Hair \& Kosmetik

- Marcel's Toy — \& Antik-Shop;

Other examples combine German and Italian:

- La libreria - italienische Buchhandlung;

German and Swedish:

- Bitte keine Reklame in diesen Briefkasten! — Reklam, nej tack!

Swiss German and French:

- Le confiseur - Aebischer - Spaleschoggi

Swiss German and English:

- London Tea - Teehuus Basel; Susan's Wohlfühlhuus;

Other combinations show German and Portuguese, German and Turkish, German and Thai, English and Chinese, etc. Sometimes, three or more languages are combined, for example German, Spanish and English:

- tapas, vino y más — spalenburg — restaurant $\bullet$ take-away $\bullet$ catering; 
Italian, English, French:

- Rosario's Lo Spuntino - Wine Bar Vinotheque

German, English and Tibetan or German, English and French (see Figures 1 and 2):

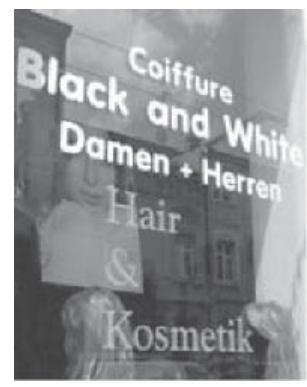

Figure 1. Trilingual hairdresser's shop window in Basel

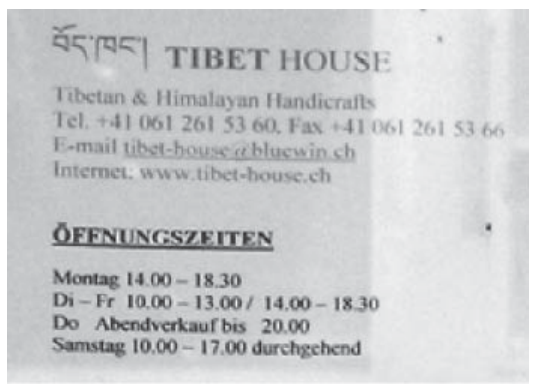

Figure 2. Trilingual inscription on the door of a Tibetan shop in Basel

That English is the language used most frequently after German is not exceptional; it is something commonly observed in many cities of the world (see the publications in Note 6). In addition, English is the most frequent working language in Basel (35.9\%) after German (97.3\%), and before French (30.6\%) and Italian (14.2\%). ${ }^{6}$ Obviously, the linguistic landscape does not reflect the distribution of the languages in the actual population (less than 2\% for English as L1, 2.5\% for French and 5\% for Italian, ${ }^{7}>11 \%$ "other languages"), but a specific plurilingual self-perception of the people of Basel which is very much linked to plurilingualism at work and in the family. The languages of immigration are visible, but under-represented (and mostly combined with German), because the lingua franca among migrants from different origins is normally 
German and because the public presence of a language is more determined by its position in the prevalent language value system than by its demographic strength; this also explains the high visibility of English which is, however, mostly combined with German, where English connotes the glamour of globalization while German ensures the understanding. Nevertheless, Basel's linguistic landscape is most intriguingly polyglossic. On the one hand, it confirms the hypothesis that plurilinguals exploit the deictic, referential, connotative and identitarian potential of their varieties in an optimal way in public literacy as in other domains of usage. Mobilizing the whole range of their resources whilst conforming to the value of each variety, they do not stick to one language at one particular time, but interweave elements of different languages most creatively. But on the other hand, it also means that the lives of people speaking different languages do not run on separate tracks, never actually meeting. The multilingual linguistic landscape raises their awareness of one another. Firstly this means the immigrants' capability of negotiating their way around public spaces in German is an indicator of their - at least passive knowledge of the local language. ${ }^{8}$ Secondly, however, the local population develops a growing familiarity with other languages and scripts, recognizing, for instance, Russian, Arabic or Thai, even without understanding the message. In the case of languages which have Latin characters, they may even identify individual words (for example in the vocabulary of gastronomy which is becoming more and more international) and develop strategies for reading comprehension. In other words, a walk through the city of Basel can provide similar results, although in an unguided, "wild" way, to language awareness teaching aides which have the goal of developing less ethnocentric language attitudes and more tolerance towards the world's linguistic diversity.

However, if we hypothesize that a plurilingual competence is a distinct feature, a kind of trademark, of modern urban populations, then we will have to find signs of this, aside from the linguistic landscape, in other observable forms of language behavior. This will be the topic of the following two chapters.

\section{Intercomprehension between various languages (the so-called "Swiss model")}

Our third example comes from a very different context: institutional communication in a computerized staff exercise carried out by a Swiss army brigade group and analyzed in a research project of the National Program of Research 56 (Altermatt and Heiniger 2008). The brigade consists of troops coming from different language regions; about half of the staff officers are German speaking and Italian speaking respectively. Some have French as their L1. In the com- 
plex, communicative space of the exercise that simulates external communication with military and civilian instances, as well as internal communication in ad-hoc working groups, formal meetings and official reports, officers with different $\mathrm{L} 1$ participate in different dyadic and polyadic, communicative events in order to resolve a common, military task.

In this setting, the Chief-of-staff (SC) of the brigade plays an important role as the conduit between the different cells and working groups, his principal task being the filtering, processing and oral passing over of information. SC is a Colonel and regular officer from the Ticino. His L1 is Italian and he is also reasonably fluent in German and French (his two other working languages), as well as in Italian dialect and Swiss German. He also speaks English.

In (3), he interacts with the head of a cell called "instruction" (G7), whose L1 is Italian, and who has a good knowledge of standard German and French and some English. Also present is a young general staff officer (Gst Of= Julien) whose dominant language is French. Prior to this meeting, G7 and Gst Of have prepared a PowerPoint presentation, in German, for the final analysis of the exercise which is to be released by SC.

$01 \quad$ G7: $\quad$ AH (.) VOILÀ (2) allora questo è il (..) der titel?

02 auch vielleicht. $+(3)+$ l'abbiamo elaborato im HINblick?! auf den nächsten aktionsführungsprozess? come del comandante?< (..) euh con un $<$ ampelsystem! > euh come il rosso $<$ kannst du bitte hier auf dem dreieck rot eh: (.) drücken? ${ }^{\circ}$ bitte $^{\circ}$ (.) voilà rot hier $($.$) siehst du der vigni-vignette >+\mathrm{xxx}^{\circ}$ ((incomprehensible sequence in German))

(..)

G7: $\quad>$ in modo che vedono $<<$ (.) rosso vuol dire (.) handlungsbedarf massiver handlungsbedarf? (.) gelb teilweise noch handlungsbedarf grün kein handlungsbedarf. >questo è unpezzo che c'è l'idea in modo che venga colorata la $($ pinta $)<=$ $=$ poi hanno [usato $\mathrm{xxx}]$ [negli / $F G G / \mathrm{s}$ ] sono i due tre che hanno fatto tutto il führungsprozess con tutti mezzi ma sono gli unici due che [xxx?] tac! andiamo sotto stärken? schwächen? 
22

23

24

25

26

27

28 SC:

29 G7

30 SC:

31 G7: et\&

[okay?]

\&puis à droite ${ }^{\circ}$ was haben wir hier hinten $?^{\circ}$ (.)

$>$ ausbildungbedarf zeitbedarf $<$ sind die punkte die

gefragt $\sin [\mathrm{d}]$ oder? (1) vedi? (.) ${ }^{\circ}$ nach dem (zu) eh nach

der\&

[eh:]

$\&(\text { gegebenen farbe })^{\circ}$

una colonna in più con handlungsbedarf allgemeines.

$<$ handlungsbedarf allgemeines? okay?>

(T_CH_Br_SC_061025_4_SC_G7_GstOf_1_02'06'00-02'14'50/Z.1-28)

How does the choice of language work in this context? Firstly, the service regulations (Dienstreglement) require the superior authority to use the language of the subordinates (Spolsky [2009] calls this "the sergeant's problem"). Secondly, among officers and particularly in the brigade's headquarters, the language in use is pragmatically negotiated, with the internal customs of staff playing an important role and the staff members' personal preferences incorporated. Thirdly, there are guidelines imposed by the head of the exercise which combine a symbolic recognition of multilingualism with its factual reduction to "the language of this exercise is (Standard) German" (the language of the computer program!)

In interviews led with the commander and the Chief-of-staff of the brigade, one maxim is adhered to namely that a staff which is linguistically mixed should choose one common "dominant" language in order to facilitate communication. During the exercise the impact of German is, of course, observable. But members of language minorities also succeed in creating free spaces for the use of other languages.

The transcribed sequence gives a good example of this. That the presentation was prepared in German reflects the guidelines. When commenting on the presentation, SC and G7 use Italian as the preferred language in this dyad. Thus, G7 comments on the working process (e.g. l'abbiamo elaborato assieme), gives further explanations (e.g. euh come il rosso), notices of intention (e.g. in modo che vedono), justifications (e.g. questo è un pezzo . . . la pinta), etc. in Italian. Both of them address themselves directly in the same language. Gst Of is supposed to understand Italian. The language choice in the pair G7 - Gst Of lacks stability; they alternate between German and French (e.g. ah voilà and et puis à droite). Later on in the exercise (in a passage not transcribed here), Gst Of will address SC in French, which corresponds to their habitual language choice. Throughout the discussion, technical terms are in German. Not only does this reflect the dominance of German in the guidelines, but also that not all Swiss military terminology exists in Italian. 
Generally speaking, SC, probably the most multilingual member of the staff, employs his multiple repertoire most flexibly and successfully, smoothly changing from Italian to German and French and vice versa according to the setting whilst relying on the - at least passive - trilingualism of all members of his staff. Furthermore, he insists in an interview that all the oral and written documents for the subordinate battalions are to be translated into their respective languages. Interestingly English is totally absent from all forms of communication observed during the exercise. As SC explains in the interview this also happens for ideological reasons "because we already have four languages in Switzerland".

The choice of language during the exercise is inconsistent, as one can expect in the case of multilingual speech (Lüdi and Py 2003 [1986]). The three individuals make very pragmatic use of all the communicative resources they share. "German only" could also be an alternative as shown in more formal contexts. But normative representations of either monolingual language usage, or of the "Swiss model", are totally absent. At the same time we get a first glimpse of existing power relations between SC and his collaborators. Communication does not, of course, occur in a "neutral space"; multilingual speakers exploit their repertoire in order to press the maximum gain out from their choice of language. Even if SC's preferred language choice is usually Italian, he never imposes it on the others, but repeatedly chooses the other's language. Thus it is evident that multilingual forms of speech can be very rewarding in a symbolic sense where it is the case of "practical goal-oriented co-operation" (Council of Europe 2001). In order to measure the success of this communicative event we do not have to assess the quality of the language(s) spoken, but we do have to answer the question of whether the goal of the interaction has been achieved. An analysis of the mutual reactions of the interacting speakers to their ongoing conversation shows that, in their perception, it certainly has been achieved. This is also true of the final evaluation of the whole exercise.

\section{Multi-addressed plurilingual speech in a business meeting}

Our fourth example is again from the DYLAN database. It was recorded in a meeting of those responsible for Human Resources in various local branches of a big department store operating nationwide (Department Store A). A young marketing assistant, $\mathrm{Hn}$, is presenting a new concept for clothing in the workplace, a kind of uniform. His dominant language is German, as it is for the majority of the audience. But several of those present at the HR meeting represent branches in the French and Italian speaking parts of the country and there 
also had been previous complaints about meetings being held exclusively in German. AP, the trilingual (Italian, French, German) head of human resources had also insisted on a certain amount of French being spoken at the meeting.

127 Hn: ok (6) gut! (1) weitere fragen zu diesem thema? (3) dann

128 nur (.) was zusätzlich hier sein wird das wissen sie wahrscheinlich jetzt auch schon (.) also wir haben (.) zur unterstützung haben wir fünfundzwanzig prozent zusätzlich (.) rabatt. rayon einundzwanzig messieurs dames dreiundzwanzig accessoires die wurden jetzt definiert welche: kategorien das heisst alles bekleidung strümpfe socken (.) in der herrenkonfektion keine! unterwäsche keine pyjamas

$140 \mathrm{Hn}$ : (.) sportbekleidung (.) das wärs. einundzwanzig dreiund-

141 AP: d'ailleurs aujourd'hui monsieur mouttet (xxx) a envoyé une une petite (.) page directive administrative

mit den kategorien

$\mathrm{AP}$ : où äh où c'est c'est où il y a encore un résumé des rayon des des groupes de marchandise je ne sais plus qui donne ä:h le droit pour avoir des (xxx) donc quelques détails à régler (xxx) (je vais faire) passer le circulaire

Hn: also jeder mitarbeiter bekommt (2) so ein blatt hä chaque ä:h (1) collaborateur reçoit une page (.) avec le strichcode avec le jä avec le code la derrière (.) ça serait intéress- äh important que le: la personne no- note sont nom là-dessus (.) c'est pas not- c'est pas noté mais c'est dans le interne gerichtlinien (.) que la personne note son nom et comme ça c'est vraiment per!sonnalisé äh aso es sött eifach dr mitarbeiter sötti mit name druf stoh ebä will die ce truc là il e:st isch gültig ${ }^{\circ}$ gültig [comment dit-on] ${ }^{\circ}$ ?

161 Hn: \&oui oui immer wieder (verwandbar) (oder;oui)?

162 MG: (on peut toujours l'utiliser)

163 Hn: jusqu'au trente et un octobre après (plus) 
The main difference between this and the preceding examples is that this is not taken from a "normal" conversation, but from a presentation to a large audience, in a communicative event that corresponds to the so-called presentation mode. This does not mean, however, a monologue by Hn because he is frequently interrupted by other participants' with words of support (1.157) and comments (1. 138-147). The presentation is multimodal, Hn making use of visual and material resources (for example 1. 148s. "so ein blatt" / "une page"), some distributed in advance to all members of the audience. It is also plurilingual. In correspondence with the maxim for internal communication between the headquarters and the branches ("use the language of the branch's language region") the material was distributed, in advance, in the three official languages (German, French and Italian). Hn decides also to make his presentation bilingual in German and French despite the fact that all members of the audience are supposed to understand both languages. Indeed, the recruitment policy of Department Store A demands at least receptive bilingualism from all its HR managers. Drawing on this fact Hn does not employ both languages with equal frequency (the presence of French is somewhat symbolic). Some short sequences are translated, but it is far from being every utterance. For the rest of the time he freely switches from German to French and vice versa. Speaking much better German than French (as can be seen in his syntax and the frequency of sequences of collaborative lexical work such as in lines 156-158 and 1. 160s.) he chooses a mode which is at the same time "exolinguistic", i.e. characterized by asymmetrical competences (usually between native and non native speakers) and the use of specific techniques to avoid or overcome stumbling blocks (Lüdi 2003), and "bilingual", for example, when he relies on German technical words (like strichcode in 1. 149), but also more generally when he switches to French (for example 1. 131, 148). Generally speaking the exolinguistic-bilingual mode of speaking reflects the asymmetry of Hn's competences, but at the same time respects the reciprocal, proportional and receptive bilingualism of his audience. Thus other participants feel free to use French too (AP in 1.141 and 144, JP in 1. 160).

\section{A team meeting in a research laboratory at Pharma $A$}

Finally let us turn to the analysis of a team meeting in a small research laboratory. The participants were: Jamal H., the head of the lab (his repertoire of languages comprises Arabic, French, English, Dutch and a bit of German), Mara S., a Hungarian lab assistant speaking Hungarian, Russian and German, two German speaking lab assistants/technicians with a rather good command of English, Sibylle G., Marianne L., and Nina S., a colleague from another lab. 
We will concentrate on three extracts. The first one comes right at the beginning of the meeting, when Jamal H. assigns Marianne L. the first task, namely the presentation of an experience protocol (written in German):

$19 \mathrm{JH}:$ so (..) ya eh we start because nina you are

20 leaving you want to leave $=$

21 NS: =yes=

$22 \mathrm{JH}: \quad=$ in fifteen minutes so we start with this

23 protocol

24 NS: $\mathrm{mmh}$

$25 \mathrm{JH}: \quad$ if you have feedback (...) who wants maybe

26 marianne you can summarize in german ya what's

$27 \quad$ eh you did

28 ML: mmh

$29 \mathrm{JH}:$ and what you expect

30 ML: $\quad$ mmh (...) also wir haben jetzt das rpmi

31 protokoll (.) aufgemöbelt (.) aufdatiert (.) und

$32 \quad$ zwar haben wir diesen faktor (.) diesen

33 verdünnungs- eh fakt- correction factor noch

34 reingegeben $=$

35 NS: $=m m h=$

36 ML: =wegen dem medium das man noch beigibt im

$37 \quad$ vergleich zu dem s9

38 NS: mmh ok

In the second extract, several minutes later, the discussion on the "correction factor" continues:

176 NS: so i think we can write like this with eh müssen mit

177 einem faktor von ehm=

$178 \mathrm{JH}: \quad$ ein komma drei

179 NS: und eh aufgerechnet ist kein deutsches wort multipliziert

$180 \mathrm{JH}: \mathrm{mmh}$

181 NS: ja recources is not for the calculation the right word

182 aso multipliziert werden um die gewünschte konzen-

183 tration zu erreichen und dann würd ich den satz dazu-

184 machen einfach um zu\&

$185 \mathrm{JH}: \quad=\mathrm{mmh}=$

186 NS: \&erklären (..) wie es dann zu den auch verschiedenen

187 abkürzungen hier kommt weisch so nen correction

188 factor das beinhaltet salzfaktor und substanzgehalt (.)

189 und dann eben dieser verdünnungsfaktor= 
190 ML: =jo salz git's jo nüm

$191 \mathrm{JH}:$ maybe then

192 NS: =and then and then the calculation Ja

$193 \mathrm{JH}:$ then here that should be the same (.) you say you ex-

194 plained between brackets it takes äh (.) yeah one thing

195 you could do (.) either you do this nullkomma-fünfsechs

196 milliliter medium without $\mathrm{s} 9$ then we have one correction

197 factor dilution factor (.) or you want to keep with s9

198 difference or without $\mathrm{s} 9$ we discussed (.) because if you

199 want to do a difference then you will have two correction

200 factors

In a third extract taken towards the end of the meeting, Jamal H. looks ahead to the work of the coming weeks and suddenly addresses Mara S.:

1239 JH: [then it's very good] it's really

1240 really good because then mara

1241 MS: ((elle sursaute)) was müssen wir?

1242 JH: kein problem mara ha:: hat eh microkern $\mathrm{xxx}$ drei

1243 oder vier? (.)dann wir braucht nichts mehr

1244 gendata bis september oder oktober

In an interview after the meeting, we presented Jamal H. with this recording and asked him to comment on the language choices. First he affirmed the dominance of English in the workplace at Pharma A, but secondly acknowledged the presence of other languages (in his lab German, in Lab A French). Here an example of his representations of the language use in his lab in his own wording:

Tous les rapports doivent être en anglais. Tout document officiel, le study plan, doit être en anglais. Le travail expérimental, ça peut être en allemand ou anglais. Il y a ce que nous appelons raw data, les données brutes, c'est en allemand. Les working documents, les documents avec lesquels elles [sc les laborantines] travaillent, sont en allemand, et ça, c'est un peu toléré parce qu'on est en Suisse. C'est un mélange. Parfois c'est intéressant, mais je ne me rends pas compte quand je parle et parfois il y a un mélange linguistique

[All the reports must be in English. Every official document, the study plan, must be in English. Experiments can be in German or English. They are what we call raw data, it's in German. The working documents with which the assistants work are in German, and this is kind of tolerated because we are in Switzerland. It's a mixture. Sometimes it's interesting, but I'm not aware any more when I speak and sometimes it's a mixture of languages.] 
The analysis of the quoted extracts fully confirms this statement. Two parameters determine our interpretation: (a) the participants do not share a common L1, thus the interaction is again exolinguistic; (b) they do not restrict themselves to one of the languages in their repertoires, but employ two of them simultaneously. The interaction is bilingual and thus we are able to observe instances of exolinguistic-bilingual speech ${ }^{9}$. Along with the conceptual framework of DYLAN, we insist less on the discursive functions of the codeswitching (as Gumperz [1982], Auer [1998] or Myers Scotton [1993] did for endolinguistic-bilingual situations; see Lüdi [2005] for an overview) than on concepts like efficiency and fairness (Gazzola and Grin 2007; Grin 2008). In the extracts quoted, one can, for example, ask oneself why Jamal H. asked Marianne L. to speak German (1. 26), why Marianne L. chose the English term "correction factor" whilst speaking German (1. 33), why Nina S. switched to German (1. 176), why Jamal H. turned to German (1. 178, 1. 195) and decided to address Mara S. in this language (1. 1242s.). Without being able to go into details, let us mention here a couple of tensions that make language choice unpredictable:

English as the dominant language of the company (and of science) weighs heavily on terminological choices, even when other languages are spoken. The reformulation by Marianne L. (1. 32s.) indicates that the English term in a German sentence is the right word. This choice is later corroborated by other members of the team who reuse the same technical term. Examples of this phenomenon are numerous and can be explained in terms of semantic transparency and cognitive economy.

The participant related code-switching of Jamal H. when addressing Mara S. (1. 1241s.) is a mark of his strategy of accommodating those among his subordinates for whom he deems it necessary. He himself strengthens this explanation when he says:

Mara ne comprend pas assez l'anglais et je sais que Marianne s'exprime mieux en allemand qu'en anglais. Pour moi, le plus important c'est qu'ELLES s'entendent et se comprennent sur les changements qu'ils vont faire à ce protocole, parce que c'est un document qu'ELLES utilisent chaque jour pour travailler.

[Mara doesn't understand enough English and I know that Marianne speaks better German than English. For me, it is most important that THEY get along with each other and understand the changes they will apply to this protocol, because it's a document THEY use daily in their work.]

For him, it is a matter of maintaining a relationship of confidence. He has been working with Mara S. for a long time and recognizes quickly whether she understands him or not: 
Si je sais qu'une personne parle allemand, j'essaie de parler l'allemand. J'utilise mon bagage linguistique et si je ne trouve pas les mots, je saute en anglais, ou vice-versa ou si je vois qu'elle comprend l'anglais, je ne change pas en allemand. C'est une adaptation, parlant avec elle, je regarde comme elle réagit, parce que avec le temps, je reconnais quand elle comprend et quand elle ne comprend pas. Si elle dit qu'elle n'a pas compris, je le dis en allemand.

[If I know that somebody speaks German, I try to speak German. I make use of my linguistic luggage and if I don't find the words, I jump to English, or vice-versa or if I see that she understands English, I don't switch to German. It's an accommodation, speaking with her, I observe how she reacts, because by and by, I recognize when she understands and when she doesn't understand. If she tells me she didn't understand, I say it in German.]

Tolerating or even imposing German, the preferred language of his subordinates in which he is not really proficient, can be explained by his concern for being efficient and productive. In another part of the collaborative assessment of our recordings, he elaborates on this dimension of efficiency:

Elle doit comprendre le message dans le temps le plus court possible. Ça ne sert à rien de parler en anglais et puis je dois réexpliquer, redire et (attendre qqn à traduire), donc j'essaie de faire traducteur en même temps. Donc là, c'est vraiment pour faciliter, c'està-dire pour que tout le monde se sente à l'aise, tout le monde comprenne, tout le monde sur le même niveau, et puis voilà, efficacité ça veut dire vraiment immédiatement lorsqu'on a fini la réunion tout le monde connaît déjà le message.

[She needs to understand the message in the shortest time possible. It's useless to speak English and then I have to explain it again, to tell it again, to wait for somebody to translate, so I try to be a translator myself. So here, it is really to facilitate things, that is to make everyone feel at ease, everyone understands, everyone at the same level, and that is it, efficiency means in fact, immediately, when a meeting is finished, everyone already knows the message.]

The experience protocol to be discussed in this meeting is written in German. The attempts at correction thus generate a conflict between the language of the protocol and the preferred language of Jamal H. This explains his use of German (1. 178, 1. 195), but also the language choice of Nina S. (1. 176) before accommodating herself to the language of her colleague.

These examples confirm the fact that partially shared plurilingual repertoires are perceived by the participants as resources to be used according to the situation, i.e. in a "situated way" (Mondada 2001; Pekarek Doehler 2005; Lüdi 2007d) and as contributing to configure research activities in dyadic and polyadic interactions in the workplace. The participants' linguistic profiles (i.e. the configuration of their linguistic competences or rather of the representation 
they have of their respective competences) and their shared knowledge about schemes of action determining types of tasks (e.g. the discussion and correction of an experience record) lead, in Lab B, to a variable language choice and to plurilingual speech, all of this, of course, taking into account social rules (hierarchy, politeness), the participants' unequal linguistic means, accepted customs and the degree of monitoring that takes place (Lüdi and Py 2003 [1986]).

Let us quote for a last time Jamal H. who explains the reasons for his behavior:

Parce qu'au quotidien, on ne se rend pas compte comment on jongle avec les langues. Le but c'est vraiment de passer le message et d'être efficace. On n'a pas le temps à perdre. Et là c'est clair la communication, la langue c'est primordial.

[Because in daily life, you don't realize how you juggle with the languages. The goal is to pass over the message and to be efficient. We don't have time to lose. And here, it's clear, the communication, the language is most important.]

\section{Perspectives}

A very flexible use of multilingual resources at work has been reported frequently in European research (Kleinberger 2003, 2004; Mondada 2004; Kameyama and Meyer 2007; etc.). This was not for the purpose of criticizing the communicative maxim underlying the model of English as lingua franca, but rather of showing which alternatives are used in the workplace in a multilingual environment. In addition, important differences have been observed between the language choices prescribed by the companies' management and the modalities chosen by participants in authentic interaction (Kleinberger 2003; Lüdi et al. forthcoming).

One could of course argue that alternative forms of behavior are only possible in countries like Switzerland in general or the Upper Rhine region in particular, with their noteworthy degree of traditional plurilingualism. So, should we thus speak of a "Swiss model" (cf. Lüdi 2007a)? Indeed, one cannot deny that external conditions exert an influence on the speakers' behavior. This might lead to the opinion that Switzerland's long history of French - German, Italian - German, etc. intercommunity communication - and an education policy that favored the learning of a second national language — contributed to the construction of a culture of communication which could involve a higher acceptance of "mixed" speech compared with other parts of the world. Because an existing system of linguistic values determines which "linguistic capital" the knowledge and use of one or the other variety conveys (Gumperz 1982; Bourdieu 1982). 
However, we doubt that the situations described are exceptional. This claim is not only grounded in the increasing plurilingualism mentioned at the beginning, but also on theoretical arguments. The fact that language choice is highly unstable, very dynamic and permanently renegotiated among the participants wherever different languages enter into contact suggests that we should question the traditional representations of what a - monolingual or multilingual - competence in language(s) is. One could advance this observation in two directions:

1. If we conceive the multilingual competence as an integrated whole, formed by partial competences in all the varieties (languages and dialects) that the repertoire of the multilingual person consists of, then we have to include a "strategic competence" (Council of Europe 2001), i.e. the mastery of exolinguistic and multilingual communication techniques such as we have observed previously. In other words, we continue to press for a new focus, within the field of linguistics, on the multilingual speaker/hearer (cf. Lüdi 2004, 2006). We would even dare to interpret the "perfect" knowledge of one language only as a "partial competence".

2. The presence of a diversity of languages in the workplace is often considered a problem rather than an asset in the ongoing shift of European societies towards greater multiculturalism and plurilingualism (Kameyama and Meyer 2007: 7). The analysis of a number of significant examples of interaction in professional contexts allows the conclusion that companies and their employees invent several, rather creative ways of dealing "locally" with multilingual repertoires. The use of English as lingua franca manifestly represents a solution frequently adopted, but no way is it the only one. Partial competences in various languages as objectives (Council of Europe 2001) together with new forms of foreign language teaching and learning (e.g. the intercomprehension model as proposed by the EuroCom program [cf. for example, Mc Cann et al. 2003]) could also involve, with time, a move towards various forms of multilingual speech, specifically in situations where there is no "natural" language contact. An important accent will lie on exolinguistic-plurilingual forms of interaction, be it in situations of reciprocal, asymmetric competences, as in the case of example (3) (receptive plurilingualism, cf. ten Thije and Zeevaert 2007), be it the different ways the various languages are used by the same speakers, as in examples (2), (4) and (5) (Mondada 2004) or be it - in marginal cases — in the form of emergent, pidgin-like varieties (Lüdi et al. 2009).

3. If we reject the "essentialist" conception of language that underlies many modern, linguistic theories, at least since Herder (1891 [1794]), then we will have to focus, on the contrary, on the situated, localized and negotiated use of variable linguistic resources that draw upon the multiple 
repertoires of all the participants in the interaction (Lüdi 2006). Communicative competences are extremely sensitive to context. In the light of models that stress the collective dimension of social action and cognition (e.g. Resnick et al. 1991), there is justification for the theory that linguistic resources are constructed, formatted and implemented in the framework of concrete, practical, common linguistic activities of the users. Following Franceschini (1998, 1999), Pekarek Doehler (2005) and others, we are sceptical about individualizing, context-free and autonomous (i.e. from other dimensions of social competence) conceptions of language competence. This is particularly important for constructing models of plurilingual communication. A broad consensus begins to emerge that "the human language faculty has an endowment for multilingualism" (Meisel 2004). In the light of new research results, this cannot mean the predominant use of one single language at any given time (cf. Mondada 2004). The mobilization of the participants plurilingual resources happens in situ, not consecutively but in one common movement, is frequently not determined in advance, but organized and negotiated by the participants themselves. The latter assemble all their possibilities, which are reconfigured constantly at the same time.

In this sense, the forms of plurilingual communication here described - which might not be very "Swiss", indeed - could serve as the kind of models of plurilingual interaction which will be used in the future to help in the management of the growing diversity of the European Union as we search for a "plurilingual answer" (Umberto Eco) to the communicative problems of a world characterized by growing globalization.

\section{University of Basel}

Correspondence addresses: georges.luedi@unibas.ch;

Katharina.Hoechle@unibas.ch; P.Yanaprasart@unibas.ch

\section{Notes}

1. All of the following examples where the source is not explicitly mentioned were tape recorded by the Basel team of the DYLAN project. This is an integrated project from the European Union>s Sixth Framework Program, Priority 7, "Citizens and governance in a knowledge based society". Nineteen partners, from twelve countries address the core issue of whether and, if so, how a European knowledge-based society designed to ensure economic competitiveness and social cohesion can be created despite the fact that, following enlargement, the European Union is linguistically more diverse than ever before.

2. See for example Seidlhofer 2001; Lüdi 2007 c. 
3. A positive assessment of partial competences also sheds new light on the "exolinguistic" techniques for assuring intercomprehension in the case of asymmetric competences as we will show later on.

4. One might call this model another manifestation of a monolingual ideology in the sense that accepting to understand another language could be the condition for refusing to speak it actively.

5. In a frequently quoted paper, Landry and Bourhis (1997: 25) proposed a new approach for the study of multilingual and polyglossic societies: the analysis of the linguistic landscape: "The landscape of public road signs, advertising billboards, street names, place names, commercial shop signs, and public signs on government buildings combines to form the linguistic landscape of a given territory, region or urban agglomeration." Cf. Gorter (2006); Backhaus (2007) and Shohamy and Gorter (2008) for bibliographical overviews. As for the focus on poly-/heteroglossic urban areas see Calvet (1990) for Paris; Bagna and Barni (2005) for Rome; Backhaus (2007) for Tokyo; Lüdi (2007b) for Basel.

6. See Lüdi et al. 2005 for a detailed analysis of the demolinguistic situation in Switzerland conforming to the National Census 2000.

7. All the figures are from the National Census 2000.

8. See Lüdi et al. [1997] and Lüdi et al. [2005] for the integration of the host language in their oral family repertoire.

9. See Lüdi 2003 for a full discussion of the different forms of speech at the crossing between two continua: monolingual — plurilingual and endolinguistic — exolinguistic.

\section{References}

Altermatt, Bernhard \& Monika Heiniger. 2008. Sprachgebrauch und Umgang mit Mehrsprachigkeit in der Schweizer Armee (am Beispiel einer mehrsprachigen Brigade). Basel: Schlussbericht NFP 56.

Auer, Peter (ed.). 1998. Code-switching in conversation. London: Routledge.

Backhaus, Peter. 2007. Linguistic landscapes. A comparative study of urban multilingualism in Tokyo. Clevedon: Multilingual Matters.

Bagna, Carla \& Monica Barni. 2005. Dai dati statistici ai dati geolinguistici: Per una mappatura del nuovo plurilinguismo. Studi Italiani di Linguistica Teorica e Applicata 34(2). 329-355.

Barère, Bertrand. 1794. Rapport du Comité de salut public sur les idiomes du 8 pluviôse an II. http://www.tlfq.ulaval.ca/axl/francophonie/barere-rapport.htm

Berchtold, Célia. 2009. La communication interne au sein de l'entreprise Pharma B à Bâle. Bâle: Institut d'Etudes françaises et francophones.

Berthoud, Anne-Claude. 2008. Le projet DYLAN 'Dynamiques des langues et gestion de la diversité'. Un aperçu. Sociolinguistica 22. 171-185.

Bono, Mariana. 2008. Ressources plurilingues dans l'apprentissage d'une troisième langue: aspects linguistiques et perspectives didactiques. Paris: Thèse de l'Université Paris III.

Bono, Mariana \& Sofia Stratilaki. 2009. The M-factor, a bilingual asset for plurilinguals? Learners' representations, discourse strategies and third language acquisition in institutional contexts. International Journal of Multilingualism 6(2). 207-227.

Bourdieu, Pierre. 1982. Langage et pouvoir symbolique. Paris: Fayard.

Calvet, Louis-Jean. 1990. Des mots sur les murs: une comparaison entre Paris et Dakar. In Robert Chaudenson (ed.), Des langues et des villes, 73-83. Paris: Agence de coopération culturelle et technique. 
Canale, Michael \& Merrill Swain. 1980. Theoretical bases of communicative approaches to second language teaching and testing. Applied Linguistics 1. 1-47.

Charles, Mirjaliisa. 2007. Language matters in global communication. Journal of Business Communication 44. 260-282.

Council of Europe. 2001. Common European framework of reference for languages: learning, teaching, assessment. Cambridge: Cambridge University Press.

Duchêne, Alexandre. 2009. Marketing, management and performance: multilingualism as commodity in a tourism call centre. Language Policy 8. 27-50.

Eco, Umberto. Comment in a French newspaper (Le Monde 7 Oct 1994).

Fichte, Johann Gottlieb. 1808. Reden an die Deutsche Nation. Berlin: In der Realschulbuchhandlung. Franceschini, Rita. 1998. Code-switching and the notion of code in linguistics: proposals for a dual focus model. In Peter Auer (ed.), Code-switching in conversation. Language, interaction and identity, 51-74. London: Routledge.

Franceschini, Rita. 1999. Italiano di contatto: parlanti occasionali e riattivazioni di conoscenze non focalizzate. Basel: Habilitationsschrift, Philosophische Fakultät der Universität Basel.

Gal, Susan. 1986. Linguistic repertoire. In Ulrich Ammon, Norbert Dittmar, Klaus J. Mattheier \& Peter Trudgill (eds.), Sociolinguistics: an international handbook of the science of language and society, 286-292. Berlin: Walter de Gruyter.

Gazzola, Michele \& François Grin. 2007. Assessing efficiency and fairness in multilingual communication: towards a general analytical framework. AILA Review 20. 87-105.

Gorter, Durk (ed.). 2006. Linguistic landscape: a new approach to multilingualism. [Special issue.] International Journal of Multilingualism 3(1).

Grégoire, Henri. 1794. Rapport sur la Nécessité et les Moyens d'anéantir les Patois et d'universaliser l'Usage de la Langue française du 16 prairial an II. http://www.tlfq.ulaval.ca/ axl/francophonie/gregoire-rapport.htm

Grin, François. 2008. Un aspect de la transversalité dans le projet DYLAN: 'Efficience et équité'. Présentation lors du colloque VALS/ASLA 2008: Sociétés en mutation - les défis méthodologiques de la linguistique.

Grosjean, François. 1985. The bilingual as a competent but specific speaker-hearer. Journal of Multilingual and Multicultural development 6. 467-477.

Grosjean, François. 2001. The bilingual's language modes. In J. L. Nicol (ed.), Language Processing in the Bilingual. Oxford: Blackwell. 1-25.

Gumperz, John. 1982. Discourse strategies. Cambridge: Cambridge University Press.

Herder, Johann Gottfried von. 1891 [1794]. Briefe zur Beförderung der Humanität. In B. Suphan (ed.), J. G. V. Herder: Sämtliche Werke, vol. XVII. Berlin: Weidmannsche Buchhandlung.

Kameyama, Shinichi \& Bernd Meyer (eds.). 2007. Mehrsprachigkeit am Arbeitsplatz. Frankfurt a.M: Peter Lang.

Kleinberger Günther, Ulla. 2004. Kommunikation in Betrieben. Wirtschaftslinguistische Aspekte der innerbetrieblichen Kommunikation. München: Peter Lang.

Kleinberger Günther, Ulla. 2004. Wirtschaftslinguistik und Mehrsprachigkeit, Babylonia 2004/4, 36-39.

Landry, Rodrigue \& Richard Y. Bourhis. 1997. Linguistic landscape and ethnolinguistic vitality: an empirical study. Journal of Language and Social Psychology 16. 23-49.

Louhiala-Salminen, Leena, Mirjaliisa Charles \& Anne Kantkaaranta. 2005. English as a lingua franca in Nordic corporate mergers: two case companies. English for Specific Purposes 24(4). 401-421.

Lüdi, Georges. 2003. Code-switching and unbalanced bilingualism. In Jean-Marc Dewaele, Alex Housen \& Li Wei (eds.), Bilingualism: beyond basic principles. Festschrift in honour of Hugo Baetens Beardsmore, 174-188. Clevedon: Multilingual Matters. 
Lüdi, Georges. 2004. Pour une linguistique de la compétence du locuteur plurilingue. Revue française de linguistique appliquée 9(2). 125-135.

Lüdi, Georges. 2005. Code-switching/Sprachwechsel. In Ulrich Ammon, Norbert Dittmar, Klaus J. Mattheier \& Peter Trudgill (eds.), Sociolinguistics: an international handbook of the science of language and society, 2nd edn., vol. I, 341-350. Berlin \& New York: Walter de Gruyter.

Lüdi, Georges. 2006. Multilingual repertoires and the consequences for linguistic theory. In Kristin Bührig \& Jan D. ten Thije (eds.), Beyond misunderstanding. Linguistic analyses of intercultural communication, 11-42. Amsterdam: John Benjamins.

Lüdi, Georges. 2007a. The Swiss model of plurilingual communication. In Jan D. ten Thije \& Ludger Zeevaert (eds.), Receptive multilingualism. Linguistic analyses, language policies and didactic concepts, 159-178. Amsterdam \& Philadelphia: John Benjamins.

Lüdi, Georges. 2007b. Basel: einsprachig und heteroglossisch. Zeitschrift für Literaturwissenschaft und Linguistik 148. 132-157.

Lüdi, Georges. 2007c. Braucht Europa eine Lingua franca? In Roswitha Fischer (ed.), Herausforderungen der Sprachenvielfalt in der Europäischen Union, 128-148. Baden-Baden: Nomos.

Lüdi, Georges. 2007d. De la compétence linguistique au répertoire plurilingue. Bulletin suisse de linguistique appliquée 84. 173-189.

Lüdi, Georges, Lukas A. Barth, Katharina Höchle \& Patchareerat Yanaprasart. 2009. La gestion du plurilinguisme au travail entre la 'philosophie' de l'entreprise et les pratiques spontanées. Sociolinguistica 23. 32-52.

Lüdi, Georges, Katharina Höchle \& Patchareerat Yanaprasart. Forthcoming. Dynamiques langagières et gestion de la diversité: l'exemple d'une grande entreprise pharmaceutique internationale basée en Suisse. In Paul Danler et al. (eds.), Actes du XXV Congrès International de Linguistique et Philologie Romanes.

Lüdi Georges \& Bernard Py. 2003 [1986]. Etre bilingue. 3rd edn. Berne et al.: Lang.

Lüdi, Georges \& Bernard Py. 2009. To be or not to be . . . a multilingual speaker. International Journal of Multilingualism and Multiculturalism. 6:2, 154-167.

Lüdi, Georges; Iwar Werlen,.in collaboration with Sarah Colombo, Philippe Lüdi, Max Mader, Kerstin Schmidt and Fee Steinbach. 2005. Le paysage linguistique en Suisse. Neuchâtel: Office fédéral de la statistique (Statistique de la Suisse. Recensement fédéral de la population 2000).

Lüdi, Georges, Iwar Werlen, Rita Franceschini, en collaboration avec Franceesca Antonini, Sandro Bianconi, Jean-Jacques Furer, Christine Quiroga, Ewald Weber et Adrian Wyman 1997. Le paysage linguistique de la Suisse. Berne: Office fédéral de la statistique (Statistique de la Suisse. Recensement fédéral de la population 1990).

Mc Cann, William J., Horst G. Klein \& Tilbert D. Stegmann. 2003. EuroComRom - The seven sieves: how to read all the Romance languages right away. Aachen: Shaker Publishing.

Meisel, Jürgen. 2004. The bilingual child. In T. K. Bhatia \& W. C. Ritchie (eds.), The handbook of bilingualism, 91-113. Oxford: Blackwell.

Mondada, Lorenza. 2001. Pour une linguistique interactionnelle. Marges linguistiques 1. 142-162.

Mondada, Lorenza. 2004. Ways of 'Doing Being Plurilingual' in international work meetings. In Rod Gardner \& Johannes Wagner (eds), Second language conversations, 27-60. London: Continuum.

Myers-Scotton, Carol. 1993. Social motivations for code-switching: evidence from Africa. Oxford: Clarendon Press.

Pekarek [Doehler], Simona. 1999. Leçons de conversation: dynamiques de l'interaction et acquisition de compétences discursives. Neuchâtel \& Paris: Delachaux \& Niestlé.

Pekarek Doehler, Simona. 2005. De la nature située des compétences en langue. In Jean Paul Bronckart, Ecaterina Bulea \& Michèle Puoliot (eds.), Repenser l'enseignement des langues: 


\section{G. Lüdi et al.}

comment identifier et exploiter les compétences?, 41-68. Villeneuve d'Ascq: Presses universitaires du Septentrion.

Resnick, Lauren B., John M. Levine \& Stephanie Teasley (eds.). 1991. Perspectives on socially shared cognition. Washington, DC: American Psychological Association.

Seidlhofer, Barbara. 2001. Closing a conceptual gap: the case of the description of English as a lingua franca. International Journal of Applied Linguistics 11(2). 133-158.

Shohamy, Elana \& Durk Gorter (eds.). 2008. Linguistic landscape. Expanding the scenery. London: Routledge.

Spolsky, Bernard. 2009. Language management. Cambridge: Cambridge University Press.

ten Thije, Jan D. \& Ludger Zeevaert (eds.). 2007. Receptive multilingualism. Linguistic analyses, language policies and didactic concepts. Amsterdam \& Philadelphia: John Benjamins.

Vollstedt, Marina. 2002. English as a language for internal company communications. In Karlfried Knapp \& Christiane Meierkord (eds), Lingua franca communication, 87-108. Frankfurt am Main: Peter Lang. 